\title{
Growth Hormone Administration Controls Body Composition Associated with Changes of Thermogenesis in Obese KK-A ${ }^{\mathrm{y}}$ Mice
}

\author{
Chizuko Hioki ${ }^{*}, 1,5$, Toshihide Yoshida ${ }^{2,3}$, Akinori Kogure ${ }^{3}$, Kanji Yoshimoto ${ }^{4}$ and Akira Shimatsu ${ }^{1}$ \\ ${ }^{1}$ Clinical Research Institute for Endocrine and Metabolic Diseases, National Hospital Organization Kyoto Medical \\ Center, 1-1, Fukakusa Mukaihata-cho, Fushimi-ku, Kyoto, 612-8555, Japan \\ ${ }^{2}$ Department of Diabetes and Metabolism, Kyoto City Hospital, Japan,1-2, Higashi Takada-cho, Mibu, Nakakyo-ku, \\ Kyoto, 604-8845, Japan \\ ${ }^{3}$ Department of Endocrinology and Metabolism, ${ }^{4}$ Department of Legal Medicine, Graduate School of Medical Science, \\ Kyoto Prefectural University of Medicine, 465, Kajii-cho, Kamikyo-ku, Kyoto, 602-8566, Japan \\ ${ }^{5}$ Department of Oriental Medicine, Tokai University School of Medicine, 143 Shimokasuya, Kanagawa, 259-1193, \\ Japan
}

\begin{abstract}
We investigate the effects of continuous human growth hormone $(\mathrm{GH})$ therapy in young obese mice on thermogenesis. Female KK- $\mathrm{A}^{\mathrm{y}}$ obese mice $(\mathrm{n}=10)$ were injected subcutaneously with $\mathrm{GH}(3.5 \mathrm{mg} / \mathrm{kg} / \mathrm{day})$ for 30 days from 42 days old. As a control, physiological saline was administered $(\mathrm{n}=10)$. At the terminal point (71 days old), GH administration affected linear growth, and the Lee obesity index ( 3 square root body weight/nasoanal length $\times 1000)$ was significantly decreased. Rates of inguinal and perimetric white adipose pads per body weight also decreased. Free fatty acid levels decreased, while plasma insulin concentrations and homeostasis model assessment insulin resistance were increased $(\mathrm{P}<0.01)$. Plasma insulin-like growth factor $\mathrm{I}(\mathrm{IGF}-1)$ levels markedly rose $(\mathrm{P}<0.00001)$. Uncoupling protein 1 (UCP1) and UCP3 mRNA expressions in brown adipose tissue were inhibited $(\mathrm{P}<0.05)$. Continuous GH therapy changed obese body composition toward lean, however, the consequence could be the negative regulation of thermogenesis.
\end{abstract}

Keywords: GH, kk-A , obesity, IGF-1, thermogenesis.

\section{INTRODUCTION}

Growth hormone $(\mathrm{GH})$ is an anabolic hormone, promoting protein synthesis and lipolysis [1] as well as stimulating linear growth through insulin-like growth factor (IGF)-1 in humans and animals [2]. GH therapy in infants and young children with Prader-Willi syndrome (PWS) reportedly increases lean body mass, adjusted for height, into the normal range, and decreased fat tissue [3,4]. Obesity is currently a serious, worldwide public health problem and a lifelong disease requiring early intervention in or before young adulthood. GH treatment of obese individuals has previously been reported to promote a decrease in adipose tissue [5,6] and increase whole-body energy expenditure [7]. GH treatment in adult GH-deficient (GHD) patients, who show increased fat mass and reduced lean body mass, alters the body composition [8]. Morbidly obese patients display low GH secretion up to levels comparable to those found in organic GHD patients, and GH deficiency in obesity is reversible [9]. Almost $40 \%$ of morbidly obese subjects undergoing laparoscopic-adjustable silicone gastric banding (LASGB) have been shown to display subnormal GH and IGF-1 levels even 6 months after surgery [10]. A trial of GH effectiveness after bariatric surgery in 24 morbidly obese

*Address correspondence to this author at the Department of Oriental Medicine, Tokai University School of Medicine, 143 Shimokasuya, Isehara, Kanagawa 259-1193, Japan; Tel: +81-463-93-1121; Fax: +81-463-95-3327; E-mail: chioki@is.icc.u-tokai.ac.jp women (age, $36.8 \pm 11.7$ years) has been reported [11]; however, the potential effects and possible risks of these GH therapies have yet to be clarified.

In adult KK- $\mathrm{A}^{\mathrm{y}}$ obese female mice, GH-induced thermogenesis has been suggested to contribute to reductions in white adipose tissue (WAT) and increases in energy expenditure, since 10-day GH treatment stimulated UCP1 and 2 mRNA in brown adipose tissue (BAT) at 70 days after birth. UCP1, a transmembrane protein located in the inner mitochondrial membrane, allows protons to reenter the mitochondrial matrix without passing through ATP synthase. When UCP1 is functional, heat is generated, because the energy released in substrate oxidation is not conserved as ATP. Thermogenesis results from the general activation of catabolic pathways in activated BAT. UCP2 and UCP3, based on their high homology with UCP1, have been suggested to also play important roles in regulating energy expenditure $[12,13]$. Hence UCPs have been proposed as important determinants in metabolic efficiency. Furthermore, insulin resistance was ameliorated by $\mathrm{GH}$ administration [14].

Whether long-term administration modifies thermogenic activation remains unclear. We have evaluated the effects of continuous GH therapy from a young adult period on body composition, carbohydrate and lipid metabolism, and primarily thermogenesis in obese mice. When administering GH to growing animals, studies should not be limited to absolute body weight, but should also consider linear 
growth. Body development during treatment was therefore assessed by calculating the obesity index of Lee [15], which correlates with body composition $[16,17]$. As a key molecule in thermogenesis, levels of UCP gene expressions in BAT were determined.

\section{MATERIALS AND METHODOLOGY}

\section{Animals}

Five-week-old female KK- $\mathrm{A}^{\mathrm{y}}$ mice were obtained from Clea Japan (Osaka, Japan) and housed in plastic cages containing 5 animals each, maintained at $22 \pm 2{ }^{\circ} \mathrm{C}$ with a 12$\mathrm{h}$ light-dark cycle. Mice had ad libitum access to commercial powdered chow (Clea Japan) and tap water. Animal experiments were performed under the supervision of the Institutional Animal Care and Use Committee at Kyoto Prefectural University of Medicine.

After being transferred to our laboratory and kept for 1 week, 20 mice were allocated to 2 groups ( $n=10$ each). Mean body weight and body length for each group were similar. Six-week-old growing mice were treated for the next 30 days with subcutaneous injections of physiological saline (Controls) or $3.5 \mathrm{mg} / \mathrm{kg} /$ day of human GH (Humatrope; Eli Lilly \& Co., Indianapolis, IN, USA).

\section{Measurements}

Mice were weighed, and tail and body lengths (anal-tonasal distance) were measured daily for indirect computation of body composition via the Lee obesity index ([3 square root body weight $(\mathrm{g}) /$ nasoanal length $(\mathrm{cm})] \times 1000)[18,19]$ Food intake for each group was monitored by weighing the amount of chow consumed over a 24 -h period.

\section{Procedures}

Mice were subsequently anesthetized with intraperitoneal injections of sodium pentobarbital $(40 \mathrm{mg} / \mathrm{kg})$ and sacrificed by cervical dislocation $4 \mathrm{~h}$ after the final subcutaneous injection. The gastrocnemius muscle, perimetric fat pad, inguinal subcutaneous fat pad and interscapular BAT pad were removed, weighed and quickly frozen in liquid nitrogen for later analysis of UCP gene expression. Collected blood was centrifuged at $1,500 \times g$ at $4{ }^{\circ} \mathrm{C}$ for $15 \mathrm{~min}$. Plasma was separated and frozen at $-20{ }^{\circ} \mathrm{C}$ for later analysis of physical data.

\section{IGF-1, Free Fatty Acid (FFA), Insulin and Glucose Levels}

Mouse plasma insulin concentration was determined by enzyme immunoassay (EIA; Morinaga Institute of Biological Science, Yokohama, Japan) and IGF-1 was measured by immunoenzymometric assay of plasma using an OCTEA Rat/Mouse kit (Immunodiagnostic Systems, Fountain Hills, AZ). FFA levels were determined using a colorimetric method employing a commercial kit (Wako Chemicals, Osaka, Japan) and glucose levels were measured by the glucose oxidase method.

\section{Insulin Resistance}

The homeostatic index of insulin resistance (HOMA-IR) was calculated according to HOMA-IR (homeostasis model assessment $)=$ fasting insulin $(\mu \mathrm{U} / \mathrm{ml}) \times$ fasting glucose $(\mathrm{mg} / \mathrm{dl}) / 405$ [20, 21].

\section{RNA Isolation and UCP Expression Analysis by Real- Time RT-PCR}

Total RNA was isolated from 0.1-0.5 g of frozen tissue using TRIzol reagent (Gibco BRL, Gaithersburg, MD, USA), according to the instructions of the manufacturer. RNA quality and quantity were evaluated by ultraviolet spectrophotometry. cDNA synthesized was performed as described above. Total RNA $(2 \mu \mathrm{g})$ was denatured at $80^{\circ} \mathrm{C}$ for $5 \mathrm{~min}$, cooled immediately and reverse-transcribed using 100 units of Moloney murine leukemia virus reverse transcriptase (M-MLV RT; Gibco BRL), 50 pmol poly (dT) primer and $20 \mathrm{nmol}$ dNTPs in a total volume of $20 \mu \mathrm{l}$. The reverse transcription reaction was performed at $37^{\circ} \mathrm{C}$ for 60 min. Gene-specific primers corresponding to PCR targets were obtained. Forward and reverse primer sequences were: UCP1 primers, 5'- GTG AAG GTC AGA ATG CAA GC -3' and 5'- AGG GCC CCC TTC ATG AGG TC -3'; UCP2 primers, 5'- ACAAGACCATTGCACGAGAG -3' and 5'CAT GGT AAG GGC ACA GTG AC -3'; UCP3 primers, 5'ATG CAT GCC TAC AGA ACC AT -3' and 5'- CTG GGC CAC CAT CCT CAG CA - $3^{\prime}$; and $\beta$-actin primers, 5 '- ATG AAG ATC CTG ACC GAG GGT -3' and 5'- AAC GCA GCT CAG TAA CAG TCC G -3'.

Some amplification products were treated using a LightCycler system (Roche Diagnostics, Mannheim, Germany), which combines the processes of amplification and detection of PCR products by fluorescence. The amplification program consisted of 1 cycle at $95{ }^{\circ} \mathrm{C}$ with a 600 -s hold (hot start) followed by 40 cycles at $95{ }^{\circ} \mathrm{C}$ with a 15 -s hold, an annealing temperature of $55^{\circ} \mathrm{C}$ with a 5-s hold, and $72{ }^{\circ} \mathrm{C}$ with a 10 -s hold. Amplification was followed by melting curve analysis using the program, run for one cycle at $95{ }^{\circ} \mathrm{C}$ with a 0 -s hold, $65^{\circ} \mathrm{C}$ with a 15 -s hold, and $95^{\circ} \mathrm{C}$ with a 0 -s hold in the step acquisition mode.

Quantification data were analyzed using the log-linear portion of the standard amplification curve, which was identified. The crossing point was the intersection of the best-fit line through the log-linear region and the noise band. Serially diluted copy numbers of standards and cDNA samples were calculated using LightCycler software. Standard curves were generated from 5-fold serial dilutions of target and housekeeping ( $\beta$-actin) cDNA preparations. The relationship between the crossing point and the initial amount of cDNA was found to be linear. The correlation coefficient was 1 and PCR amplification efficiencies of the target gene and housekeeping gene were similar. These standard curves were used to estimate the concentration of both target and $\beta$-actin genes in each sample. Amplification products were checked by electrophoresis on $1.5 \%$ ethidium bromide-stained agarose gels.

\section{ADDITIONAL EXPERIMENT}

Plasma IGF-1 levels of 10-day-treated mice were measured via the same methods as in the above experiment .

Obese: Twenty female KK-Ay mice (Clea Japan, Osaka, Japan), and lean $20 \mathrm{C} 57 \mathrm{Bl} / 6 \mathrm{~J}$ female mice (Clea Japan, Osaka, Japan) aged 8 weeks were housed in plastic cages containing 5 animals each, under the same conditions as in the 30-day GH trial. At 9 weeks of age, the mice were divided into two groups: $3.5 \mathrm{mg} / \mathrm{kg}$ human GH-treated 
group, $\mathrm{n}=10$, and physiological saline-treated group, $\mathrm{n}=10$. Each group was injected subcutaneously with GH or saline as a control once a day, for 10 days. Body weight, anal-tonasal distance and food consumption were measured daily; The procedure followed the previous study on 10- day GHtreated mice, and no significant differences in food intake (g/day) and their growth level were observed from previous results [14]. After 10-day administration, they were anesthetized with pentobarbital sodium and sacrificed by cervical dislocation $4 \mathrm{~h}$ after the last subcutaneous injection on day 10. The collected blood samples were used for plasma IGF-1 concentrations.

\section{Statistical Analysis}

Values are the mean \pm standard error of the mean. Statistical significance was assessed using analysis of variance (ANOVA). Two-way ANOVA followed by the Bonferroni $t$-test was used when performing multiple comparisons. Results were considered significant at $\mathrm{P}<0.05$.

\section{RESULTS}

\section{Body Growth and Tissue Weights}

Obese mice treated with $\mathrm{GH}(3.5 \mathrm{mg} / \mathrm{kg})$ for 30 days exhibited a more steady linear increase than control mice in body weight and length over the treatment period. Detailed analysis of body growth demonstrated a significant and sustained stimulatory effect of $\mathrm{GH}$ after treatment for 14 days. The Lee obesity index in GH-administered mice was significantly decreased $(\mathrm{p}<0.05)$ at 55 days old, despite the increased body weight $(\mathrm{p}<0.005 v s$ Control) (Figs. 1, 2). At 71 days old, the Lee index of GH-treated obese mice was within the normal standard range of 310-320. No difference in tail length was seen between GH and control groups (data not shown).

Differences in food intake (g/day) were observed between $\mathrm{GH}$ and control mice from day 10 of treatment $(\mathrm{GH}$, Control: $6.5 \pm 0.2 \mathrm{~g}, 6.1 \pm 0.2 \mathrm{~g}$ : $\mathrm{p}<0.05$, at 52 days after birth). Each food intake average, from 52 to 61 days after birth, was $7.8 \pm 0.2 \mathrm{~g}$ in $\mathrm{GH}$ groups, and $7.2 \pm 0.1 \mathrm{~g}$ in Control groups $(\mathrm{p}<0.05)$, and Table 1 shows continuous differences after this period. Perimetric and inguinal WAT weights were significantly reduced compared to Controls, when compared with the normalized body weight at 71 days old. In contrast, the weight rate of gastrocnemius muscle increased with $\mathrm{GH}$ administration $(\mathrm{P}<0.05)$.

After GH treatment for 30 days, the plasma insulin level had increased two-fold compared with Controls, suggesting increased insulin resistance, as shown by HOMA-IR levels. Plasma IGF-1 concentrations in GH-treated obese mice were

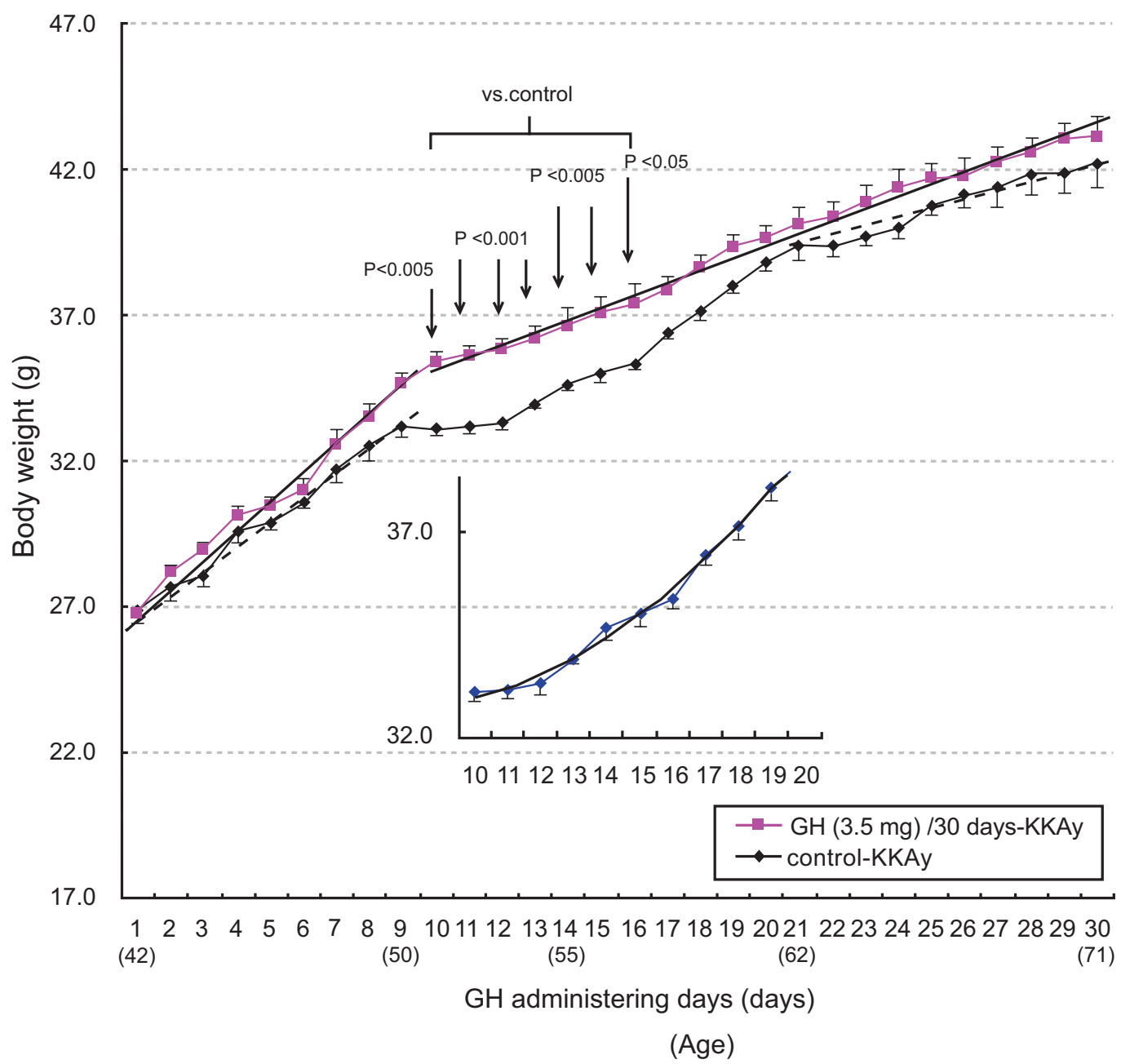

Fig. (1). Effects of GH administration on body weight in $\mathrm{KKA}^{\mathrm{y}}$ mice. Mice were treated with GH or saline for 30 days from 42 days old. Weight was gained over the whole period in both groups ( $\mathrm{n}=10 /$ group). 


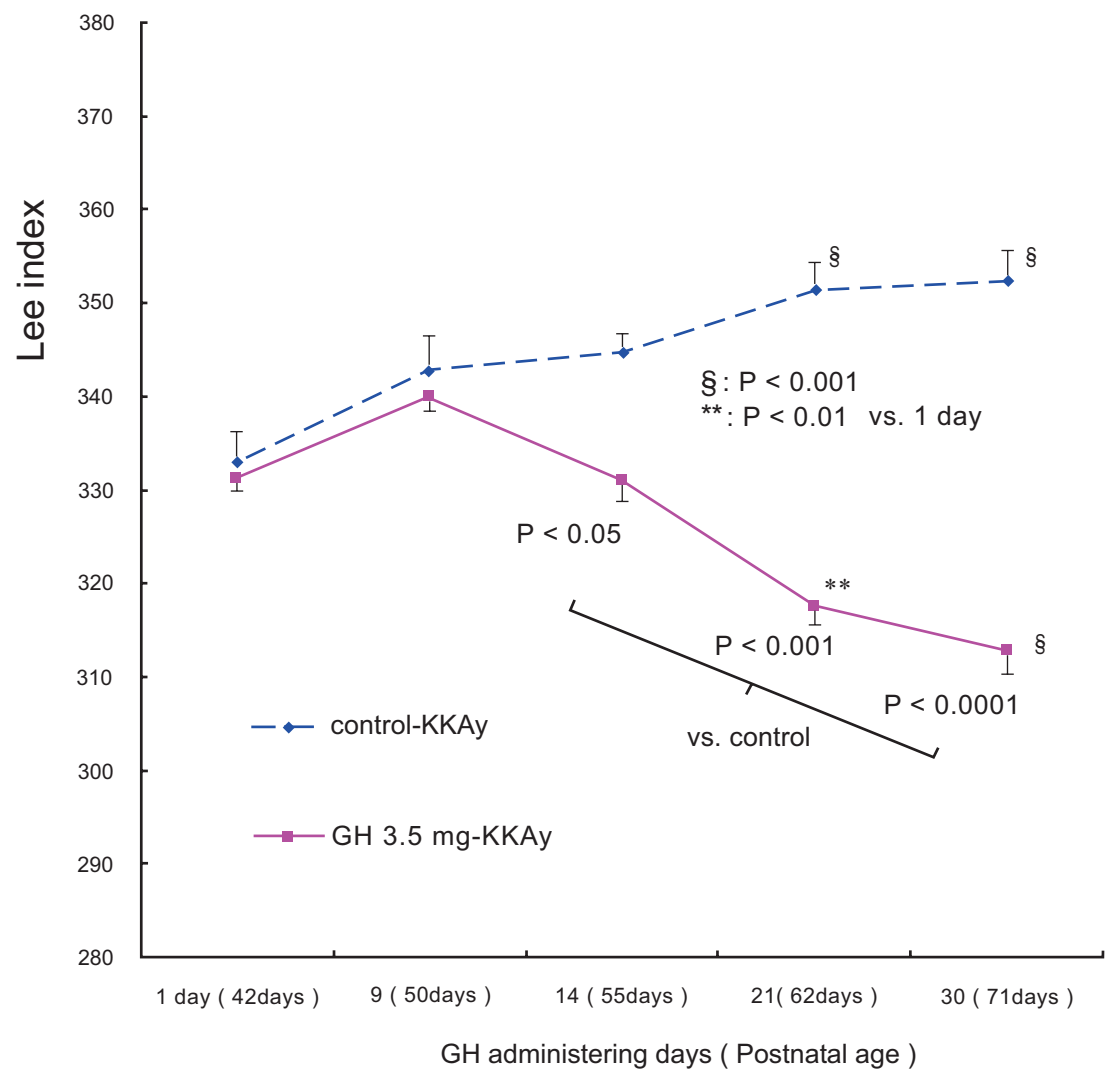

Fig. (2). Lee index as an evaluation of obesity (see Methods). Each point represents the mean \pm standard error of the mean ( $n=10 /$ group).

Table 1. Body Composition and Biochemical Details

\begin{tabular}{|c|c|c|}
\hline \multirow[t]{3}{*}{ Administering Days } & \multicolumn{2}{|c|}{30 Days (n=10) } \\
\hline & \multirow{2}{*}{$\begin{array}{l}\text { Control } \\
\text { (Saline) }\end{array}$} & GH \\
\hline & & $\begin{array}{l}(3.5 \mathrm{mg} / \\
\mathrm{kg} / \mathrm{day})\end{array}$ \\
\hline Food intake (62-71 days after birth) (g/day) & $8.5(0.3)$ & $9.0(0.4)^{\mathrm{a}}$ \\
\hline Body weight (g) & $42.2(1.3)$ & $43.1(0.7)$ \\
\hline Body length (anal-to-nasal distance) (cm) & $9.9(0.4)$ & $11.2(0.3)^{\mathrm{b}}$ \\
\hline Inguinal WAT / Body weight (\%) & $1.8(0.1)$ & $1.4(0.1)^{\mathrm{a}}$ \\
\hline Perimetric WAT / Body weight (\%) & $8.0(0.6)$ & $6.1(0.3)^{b}$ \\
\hline Gastrocnemius muscle / Body weight (\%) & $0.7(0.1)$ & $0.9(0.1)^{\mathrm{a}}$ \\
\hline Interscapular BAT / Body weight (\%) & $0.6(0.1)$ & $0.7(0.1)$ \\
\hline FFA (mEq/l) & $3.3(0.1)$ & $2.8(0.1)^{\mathrm{b}}$ \\
\hline Glucose (mg/dl) & $195.7(10.1)$ & $192.6(13.1)$ \\
\hline Insulin $(\mu \mathrm{U} / \mathrm{ml})$ & $276.1(23.3)$ & $537.6(50.1)^{b}$ \\
\hline HOMA-IR & $133.3(6.7)$ & $255.6(18.2)^{b}$ \\
\hline
\end{tabular}

All values are presented as the mean (standard error of the mean). Tissue weights were normalized by final body weights. ${ }^{\mathrm{a}} \mathrm{p}<0.05 ;{ }^{\mathrm{b}} \mathrm{p}<0.01$ vs saline control. HOMA-IR: homeostatic index of insulin resistance.

much higher than those in Controls at the terminal point. Fig. (4) shows IGF-1 levels markedly increased in response to 30-day GH administration. Moreover, IGF-1 levels in obese mice were much lower than in lean model mice $(\mathrm{C} 57 \mathrm{BL} / 6 \mathrm{~J}$, female, $\mathrm{n}=10$ : Lee index; $319.3 \pm 3.3$; plasma IGF-1, $479.1 \pm$ $20.2 \mathrm{ng} / \mathrm{ml})$. GH therapy exerted significant effects on both body composition and plasma IGF-1 responses, with total IGF-1 levels in obese mice increasing 6.0-fold compared with Controls $(\mathrm{p}<0.00001)$ after 30 -day $\mathrm{GH}$ administration (Fig. 4).

\section{Negative Regulation of UCP1 and UCP3 Genes in BAT}

$\mathrm{GH}$ administered to young growing mice for 30 days decreased UCP1 and UCP3 mRNA levels (0.7- and 0.5-fold, respectively; $\mathrm{p}<0.05$ vs Controls) in BAT (Fig. 3).

\section{DISCUSSION}

In the present continuous 30-day trial, a marked impact of $\mathrm{GH}$ administration was shown on linear growth. Young growing genetic obese mice responded to exogenous $\mathrm{GH}$ with linear increases in body weight as well as longitudinal bone growth (Figs. 1, 2). While no significant difference in tail length was seen between groups receiving GH treatment or saline, as reported by Finkelstein et al. [22], tail automutilation was sometimes observed in $\mathrm{KK}-\mathrm{A}^{\mathrm{y}}$ obese mice with GH treatment, as in monosodium L-glutamatetreated obese mice [23]. Consequently, the Lee index, reflecting percent body fat, continued to fall markedly from 55 days old to the final point in contrast to Controls, despite increased body weight (Fig. 2). Exogenous GH affected dimensions of the long bones, in accordance with the known effects of GH on longitudinal bone growth [24, 25]. 


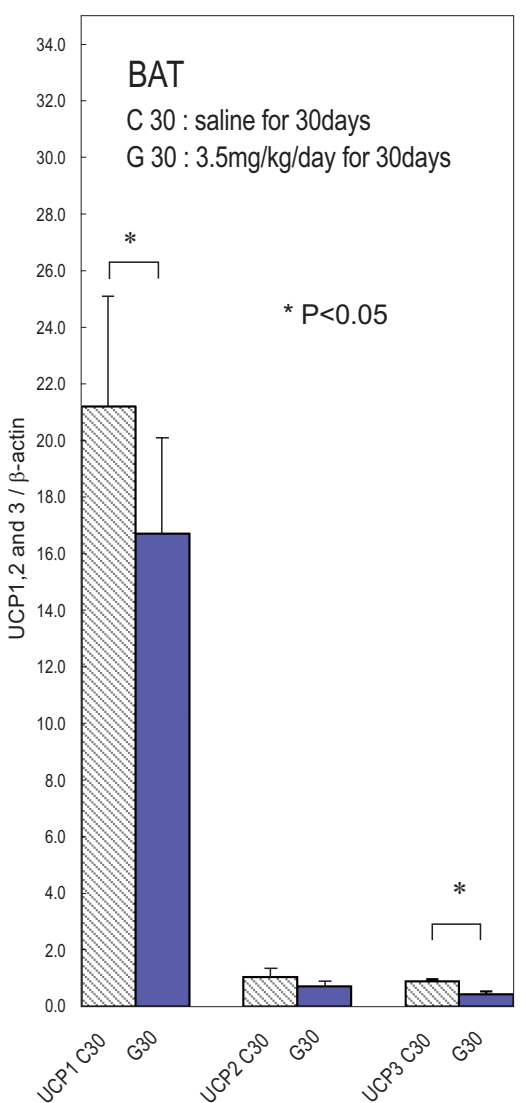

Fig. (3). The ratio between expressions of UCPs mRNA and $\beta$-actin mRNA in BAT. Hatched columns show Controls (saline treatment), and filled columns show GH treatment group.
Treatment with $\mathrm{GH}$ for 30 days resulted in significant reductions of both subcutaneous and visceral fat, and increased the relative muscle weight. Control mice showed excess perimetric and inguinal fat deposits at 71 days old (Table 1). KK-A ${ }^{\mathrm{y}}$ female mice have already been reported to show increased adipose tissue weight at about 8 weeks old, achieving maximum adipose deposits at 10 weeks old [26].

$\mathrm{GH}$ treatment $(3.5 \mathrm{mg} / \mathrm{kg} /$ day $)$ for 10 days to adult obese mice increased UCP1 and UCP2 mRNA expressions in BAT. Accompanying this up-regulation, body weight and fat pads fell over a short period, suggesting a role of UCPs in GH-modulated energy expenditure [14]. However, continuous 30-day administration of $\mathrm{GH}$ from an early stage, when mice had not gained markedly increased fat pads, showed lower expressions of UCP1 and UCP3 mRNA than saline controls in BAT. The reason for this discrepancy is unclear, but may be due to differences in the term or starting period of GH administration. IGF-1 levels in 30-day GH trial mice were much higher than in the previous 10-day trial starting in adulthood (Fig. 4), in which mice showed increased fat pads at the starting point. Obese model mice seem likely to share similar traits given report in which obese patients with low IGF-1 showed below-normal levels of $\mathrm{GH}$ [10]. With continuous $\mathrm{GH}$ treatment, adipose tissues are one of the targets of $\mathrm{GH}$ action, so the present $\mathrm{GH}$ trial seems effective as an anti-obesity protocol as the obese young mice became lean adults; however, in this present study, insulin resistance was increased despite the 10-day $\mathrm{GH}$ trial showing decreased HOMA-IR [14]. Although the present study offers limited information, increased IGF$1 /$ insulin signaling and induced food intake both appear as independent, overlapping effects. IGF-1 plays a vital role in the regulation of somatic growth and cellular proliferation, and may be used as a measure of GH bioactivity by accurately reflecting the GH secretory status [27].

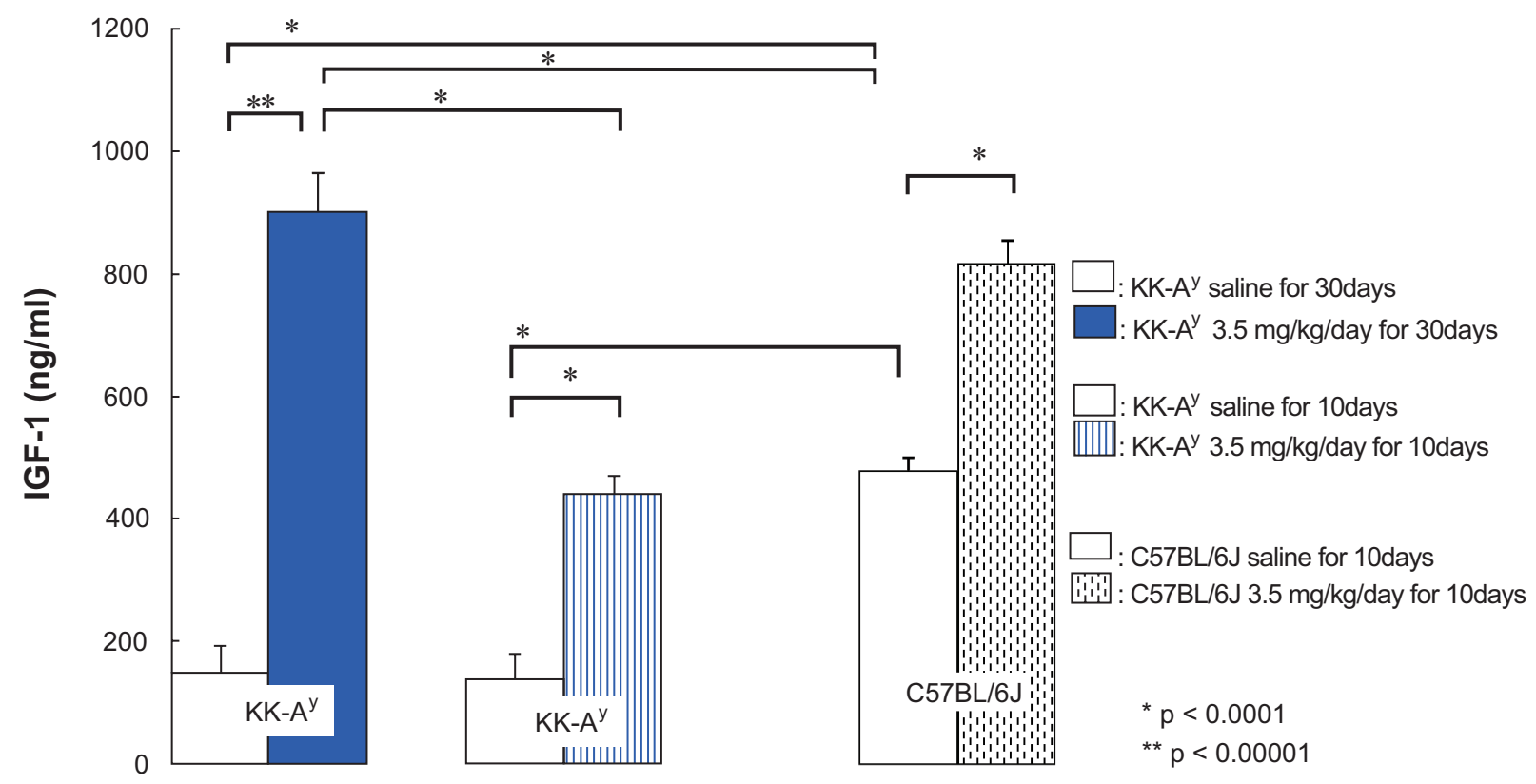

Fig. (4). Levels of plasma IGF-1 ( $\mathrm{n}=10$ /group), quantifed by ELISA. Open bars: each control group was administered saline. Other bars: IGF-1 concentrations of GH-treated group are shown. Each value is the mean \pm standard error of the mean. 
$\mathrm{GH}$ is thought to increase the basal metabolic rate through thermogenesis [14] and the induction of catecholamine release [28], increasing the conversion of the thyroid hormone $\mathrm{T} 4$ to the more metabolically active T3 [29], and increasing IGF-1 secretion, which may participate in increasing resting energy expenditure [30]. Conversely, adult KK-A $\mathrm{A}^{\mathrm{y}}$ mice with markedly elevated IGF-1 levels showed decreased UCP1 and UCP3 expressions. Continuous $\mathrm{GH}$ administration in the growing stage could bring about the reduction of thermogenesis and growth factor might affect BAT and/or brown preadipocytes. The relationship between the endocrine and metabolic changes induced by exogenous GH remains poorly studied. Further studies are required to elucidate the relation between IGF-1 and thermogenesis.

\section{ACKNOWLEDGEMENTS}

This work was supported by a Grant-in-Aid for Scientific Research from the Japan Foundation for Growth Science.

\section{REFERENCES}

[1] Davidson MB. Effects of growth hormone on carbohydrate and lipid metabolism. Endocr Rev 1987; 8: 115-31.

[2] Daughday WH, Rotwein P. Insulin-like growth factors I and 2 peptide and messenger ribonucleic acid gene structures, plasma, and tissue concentrations. Endocr Rev 1989; 10: 68-91.

[3] Eiholzer U, L'allemand D, Schlumpf M, et al. Growth hormone and body composition in children younger than 2 years with PraderWilli syndrome. J Pediatr 2004; 144: 753-8.

[4] Whitman B, Carrel A, Bekx T, et al. Growth hormone improves body composition and motor development in infants with PraderWilli syndrome after six months. J Pediatr Endocrinol Metab 2004; 17: 591-600.

[5] Richelsen B, Pedersen SB, Borglum JD. Growth hormone treatment of obese women for $5 \mathrm{wk}$ : effect on body composition and adipose tissue LPL activity. Am J Physiol 1994; 266: E211-6.

[6] Synder DK, Clemmons DR, Underwood LE. Treatment of obese, diet-restricted subjects with growth hormone for 11 weeks. Effects on anabolism, lipolysis and body composition. J Clin Endocrinol Metab 1988; 67: 54-61.

[7] Gertner JM. Growth hormone actions on fat distribution and metabolism. Horm Res 1992; 38: 41-3.

[8] Bengtsson BA, Eden S, Lonn L. Treatment of adults with growth hormone deficiency with recombinant human GH. J Clin Endocrinal Metab 1993; 76: 309-17.

[9] Maccario M, Valetto MR, Savio P, et al. Maximal secretory capacity of somatotrope cells in obesity: comparison with GH deficiency. Int J Obes Relat Metab Disord 1997; 21: 27-32.

[10] Di Somma C, Angrisani L, Rota F, et al. GH and IGF-I deficiency are associated with reduced loss of fat mass after laparoscopicadjustable silicone gastric banding. Clin Endocrinol (Oxf) 2008; 69: 393-9.

[11] Savastano S, Di Somma C, Angrisani L, et al. Growth hormone treatment prevents loss of lean mass after bariatric surgery in morbidly obese patients: results of a pilot, open, prospective, randomized, controlled study. J Clin Endocrinal Metab 2008; 94: 817-26.

[12] Vidal-Puig JA, Grugic D, Zhang CY, et al. Energy metabolism in uncoupling protein 3 gene knockout mice. J Biol Chem 2000; 21: 16258-66.

[13] Ricquier D. Respiration uncoupling and metabolism in the control of energy expenditure. Proc Nutr Soc 2005; 64: 47-52.

[14] Hioki C, Yoshida T, Kogure A, et al. Effects of growth hormone (GH) on mRNA levels of uncoupling proteins 1,2 , and 3 in brown and white adipose tissues and skeletal muscle in obese mice. Horm Metab Res 2004; 36: 607-13.

[15] Lee MO. Determination of the surface area of the white rat with its application to the expression of metabolic results. Am J Physiol 1928; 89: 24-33.

[16] Bernardis LL, Patterson BD. Correlation between 'Lee index' and carcass fat content in weaning and adult female rats with hypothalamic lesions. J Endocrinol 1968; 40: 527-8.

[17] Frohman LA, Goldman JK, Schnats JD, et al. Hypothalamic obesity in the weaning rat: effect of diet upon hormonal and metabolic alternations. Metabolism 1971; 20: 501-12.

[18] Bellinger LL, Bernardis LL, Brooks S. Feeding responses of rats with dorsomedial hypothalamic lesions given ip 2DG or glucose. Am J Physiol 1978; 235: 168-74.

[19] Bracco EF, Yang MU, Segal K, et al. A new method for estimation of body composition in the live rat. Proc Soc Exp Biol Med 1983; 174: 143-6.

[20] Haffner SM, Miettinen H, Stern MP. The homeostasis model in the San Antonio heart study. Diabetes Care 1997; 20: 1087-92.

[21] Katz A, Nambi SS, Mather K, et al. Quantitative insulin sensitivity check index: a simple, accurate method for assessing insulin sensitivity in humans. J Clin Endocrine Metab 2000; 85: 2402-10.

[22] Finkelstein JA, Jevois P, Menadue M. Growth hormone and prolactin secretion in genetically obese Zucker rats. Endocrinology 1991; 118: 1233-6.

[23] Nemeroff CB, Konkol RJ, Bissette G. Analysis of the disruption in hypothalamic -pituitary regulation in rats treated neonatally with monosodium L-glutamate (MSG): Evidence for the involvement of tuberoinfundibular cholinergic and dopaminergic systems in neuroendocrine regulation. Endocrinology 1977; 101: 613-22.

[24] Andreassen TT, Jorgensen PH, Flyvbjerg A. Growth hormone stimulates bone formation and strength of cortical bone in aged rats. J Bone Miner Res 1995; 10: 1057-67.

[25] Ohlsson C, Isgaard J, Tornell J. Endocrine regulation of longitudinal bone growth. Acta Paediatr 1993; 82: 33-40.

[26] Iwatsuka H, Shino A, Suzuoki Z. General survey of diabetic features of yellow KK mice. Endocrinol Jpn 1970; 17: 23-35.

[27] Frystyk J. Free insulin-like growth factors: measurements and relationships to growth hormone secretion and glucose homeostasis. Growth Horm IGF Res 2004; 14: 337-75.

[28] Fleming RYD, Randi LR, Farouk J, et al. Effects of recombinant human growth hormone on catabolic hormones and free fatty acids following thermal injury. J Trauma 1992; 32: 698-703.

[29] Wolthers T, Grofte T, Moller N, et al. Calorigenic effect of growth hormone: the role of thyroid hormones. J Clin Endocrinol Metab 1996; 81: 1416-9.

[30] Hussain MA, Schmitz O, Mengel A, et al. Comparison of the effects of growth hormone and insulin-like growth factor I on substrate oxidation and on insulin sensitivity in growth hormonedeficient humans. J Clin Invest 1992; 94: 1126-33. 